\title{
Artemisia annua - Importance in Traditional Medicine and Current State of Knowledge on the Chemistry, Biological Activity and Possible Applications
}

Authors

Halina Ekiert ${ }^{1}$, Joanna Świątkowska ${ }^{1}$, Paweł Klin², Agnieszka Rzepiela ${ }^{3}$, Agnieszka Szopa ${ }^{10}$

Affiliations

1 Chair and Department of Pharmaceutical Botany, Jagiellonian University, Medical College, Kraków, Poland

2 Family Medicine Clinic, Medizinisches Versorgungszentrum (MVZ) Burgbernheim GmbH, Burgbernheim, Germany

3 Museum of Pharmacy, Jagiellonian University, Medical College, Kraków, Poland

Key words

Artemisia annua, Asteraceae, annual mugwort, qinghao

received

October 16, 2020

accepted after revision

December 16, 2020

published online

January 22, 2021

Bibliography

Planta Med 2021; 87: 584-599

DOI $\quad 10.1055 / a-1345-9528$

ISSN 0032-0943

(C) 2021. Thieme. All rights reserved.

Georg Thieme Verlag KG, Rüdigerstraße 14,

70469 Stuttgart, Germany

Correspondence

Prof. Dr. hab. Halina Ekiert

Chair and Department of Pharmaceutical Botany, Jagiellonian University, Medical College

Medyczna 9, 30-688 Kraków, Poland

Phone: + 48126205430 , Fax: + 48126205440

halina.ekiert@uj.edu.pl
Correspondence

Dr. hab. Agnieszka Szopa

Chair and Department of Pharmaceutical Botany, Jagiellonian University, Medical College

Medyczna 9, 30-688 Kraków, Poland

Phone: + 48126205436 , Fax: 48126205440

a.szopa@uj.edu.pl

ABSTRACT

Artemisia annua (annual mugwort) is a species that has long been used in traditional Asian medicine, mainly Chinese and Hindu. The species is widespread and known as a medicinal plant not only in Asia but also in Europe, in both Americas, and Australia. The species has become a subject of particular interest due to the 2015 Nobel Prize awarded for detecting the sesquiterpene lactone artemisinin in it and proving its antimalarial activities. The raw materials obtained from this species are Artemisiae annuae folium and Artemisiae annuae herba. The leaves are a raw material in the Chinese Pharmacopoeia and Vietnamese Pharmacopoeia. Both raw materials are in the International Pharmacopoeia published by the WHO. The main components of these raw materials are mainly specific sesquiterpene lactones, essential oil, flavonoids, coumarins, and phenolic acids. In traditional Asian medicine, the species is used, for example, in the treatment of jaundice and bacterial dysentery, as an antipyretic agent in malaria and tuberculosis, in the treatment of wounds and haemorrhoids, and in viral, bacterial, and autoimmune diseases. Professional pharmacological studies conducted today have confirmed its known traditional applications and explain previously unknown mechanisms of its biological action and have also found evidence of new directions of biological activity, including, among others, anti-inflammatory, analgesic, antioxidant, antitumour, and nephroprotective activities. The species is of growing importance in the cosmetics industry.

\section{Introduction}

The purpose of this review is to present the current state of knowledge on the chemistry, biological activity, possible therapeutic applications, and possible uses of Artemisia annua L. (annu- al mugwort), an herbaceous plant of the genus Artemisia from the family Asteraceae (Compositae).

The awarding of the 2015 Nobel Prize in Medicine for the discovery of the sesquiterpene lactone artemisinin, found in A. annua, and proving the effectiveness of its antimalarial action have resulted in a marked increase in interest in both the chemical 
composition and biological activity of various species of the genus Artemisia [1,2]. Among them, A. annua has become an object of modern, professional scientific research with a phytochemical and pharmacological profile [3-7].

This species has an important position in traditional Asian medicine (mainly Chinese and Hindu). It is known as a medicinal plant on five continents, not only in Asia but also in Europe, the Americas, and Australia [8-11]. It was used in Asian medicine, for example, in the treatment of jaundice and bacterial dysentery, and fever in the course of malaria and tuberculosis. It was effective in the treatment of wounds and haemorrhoids, various viral and bacterial diseases, and autoimmune diseases [3, 12,13].

Nowadays, this species has the status of a pharmacopoeial species in China and Vietnam [7,14-16]. It is also listed in the International Pharmacopoeia published by the WHO. The medicinal raw materials are Artemisiae annuae folium and Artemisiae annuae herba [8].

The performed pharmacological studies explain previously unknown mechanisms of its biological action known from traditional applications. These studies also prove new directions of biological activity, including anti-inflammatory, analgesic, antioxidant, antitumour, and nephroprotective activities. Extracts from $A$. annua act against hepatitis $B$ virus, bovine viral diarrhoea, and EpsteinBarr virus [3, 17-20]. Recently, the possible application of $A$. annua in the treatment of COVID-19 is being scientifically discussed [2124].

The species has also become an object of growing interest to the cosmetics industry, especially in Europe [25]. In recent years, review articles have been published regarding various Artemisia species, with $A$. annua receiving a lot of attention $[3,5,17,18]$.

\section{General Information on the Species}

A. annua is widespread in many parts of the world, which is the reason why the plant has numerous synonymous names. The following are 14 Latin synonyms for annual mugwort, with references to their sources: $A$. annua $\mathrm{f}$. annua, $A$. annua $\mathrm{f}$. genuina Pamp., A. annua f. macrocephala Pamp., A. annua var. zelandica Lam., Artemisia chamomilla C.Winkl, Artemisia exilis Fisch, A. exilis Fisch. ex DC, Artemisia hyrcana Spreng, Artemisia plumosa Fisch, A. plumosa Fisch. ex Bess., Artemisia stewartii C. B. Clarke, Artemisia suaveolens Fisch, Artemisia wadei Edgew., Omalotheca stewartii (C. B.Cl.) J.Holub [26-28].

A. annua's English and foreign names are annual mugwort, annual wormwood, Chinese wormwood, sweet Annie, sweet sagewort, sweet wormwood (English); Cao Haozi, Cao Qinghao, Caohao, Chou Qinghao, Chouhao, Haozi, huang hua hao, jiu Bingcao, Kuhao, San Gengcao, Qinghao, Xiang Sicao, Xianghao, Xiang, Xiyehao (Chinese); Einjähriger Beifuß (German); armoise annuelle (French); sommarmalört (Swedish); Zomeralsem (Danish); Kusoninjin (Japanese); Chui-ho, Hwang-hwa-ho, Gae-tongsook (Korean); and Thanh cao hoa vàng (Vietnamese) [2, 8, 26, 27, 29, 30].

According to the Chinese Pharmacopoeia and Vietnamese Pharmacopoeia, the raw material is the dried leaves of $A$. annua (Artemisiae annuae folium) $[15,16]$. The International Pharmaco- poeia published by the WHO also lists dried A. annua herb (Artemisiae annuae herba) as a raw material [8].

A. annua is an annual herbaceous plant growing to a height of $30-100 \mathrm{~cm}$ [8]. The A. annua plant can have stems that are bare or covered with T-shaped hairs. On the leaves and flowers of the plant, in addition to T-shaped hairs, there are also glandular trichomes, which are characteristic of the Asteraceae family. The trichomes are composed of 10 cells arranged in four rows. In the upper layers, there are glandular cells filled with essential oil [8, 31]. Unlike other species of the genus Artemisia, A. annua has one main vertical violet-brown ribbed stem with smaller alternately growing offshoots $[5,8,29]$. In autumn, the stems take on a red colour [29].

The foliage of the plant has an alternate arrangement [32]. The dark green leaves of the plant are deeply divided [29]. The tripinnatisect lower leaves grow on petioles, the middle leaves are bipinnatisect, while the upper leaves are sessile and have a lanceolate shape [33]. The leaf blades themselves also differ in shape, as they can be ensiform or lanceolate. Often, the edge of the blades is serrated. Smooth bracts can be found at the base of the leaves [29].

The flower heads are collected in raceme-like inflorescences. The heads are small, spherical, and yellow-green. At the base of each head there are 6 bracts [29,33]. The head contains only tubular flowers. Along its perimeter there are female flowers, while those in the middle are bisexual. The leaves covering the head have two layers. The outer layer consists of short, ensiform leaves, while the inner layer has longer, ovoid leaves [32]. Although the leaves of the plant have a pleasant aroma, $A$. annua flowers are scentless [33]. The fruit of $A$. annua are $0.8 \mathrm{~mm}$ long achenes [32].

The species can be propagated from seeds, which germinate easily, and the seedlings grow quickly. The seeds are resistant to harsh weather conditions, both drought and cold winters. A. annua is resistant to diseases and pests, which makes it a good plant for cultivation [29]. It is an allopathic plant due to the presence of artemisinin [18].

A. annua occurs naturally in Southeastern Europe and Western Asia in the temperate zone [29,32]. At the end of the 19th century, it was brought to Western Europe and Southern Europe, and then spread to Russia, Iran, Afghanistan, Pakistan, and China $[32,33]$. Nowadays, the plant can be found in different parts of Europe and Asia, North and South America, and Australia. The largest habitats of $A$. annua are in the western United States and Western Europe [27]. The species is not native to Poland, but it can be found in the southern part of the country and in the Silesia and Lublin provinces [32].

The plant grows readily on hillsides, forest edges, and wasteland [29]. It inhabits moderately dry and nutrient-rich sites. In Poland, these are usually areas that have soil with a high humus content, loamy, gravelly, or sandy [34]. Depending on the climate zone, A. annua grows at altitudes of 50 to $1500 \mathrm{~m}$ a. s. I. [8].

A. annua is a source of artemisinin, which is used to treat malaria, hence, the species has become a cultivated plant $[8,35]$. Although the plant comes from the temperate zone, the seeds of various varieties have been successfully adapted for cultivation in many tropical countries, such as Congo, India, and Brazil [36]. Other countries where $A$. annua has become an industrial crop 
species are China, Kenya, Tanzania, and Vietnam. For industrial applications, the plant is also harvested from its natural habitats $[3,8,35]$.

A. annua is a plant that is relatively easy to grow in a temperate climate [37]. To achieve a high seed germination rate, wellaerated soil and sunlight are needed. When the soil is difficult to drain, the plant should first be grown in a greenhouse [8].

The concentration of artemisinin in the plant is highest during flowering. To maximize the yield of this compound from this species, appropriate duration of light exposure is needed because the plant grows best during long summer days and blooms when the length of the day is reduced. In the drying process, it is best to place the plants in the sun for 1 week, and then transfer them to a shady, airy place [36]. The dried leaves should not be stored for more than 6 months. If, after this time, artemisinin is to be obtained from the raw material, additional tests are required to determine its concentration in the dried product $[3,38]$. The time from sowing to harvesting the plant is 4.5 to 5 months [35].

It has been reported that the key factor to achieving a high artemisinin concentration in the plant is the use of the appropriate genetic variety of $A$. annua. One such variety is $A$. annua var. artemida. Environmental factors have a lower impact on the yield of this variety [36]. The A. annua F1 hybrid called "Artemis" (A. annua $\times$ F1 Artemis) is also recommended [39-41]. The cultivation time of the species is quite long, which translates into frequent fluctuations in the supply and prices of the products obtained from $A$. annua [18].

\section{Phytochemical Characteristics}

A. annua contains many different classes of compounds and is a plant with a variable chemical composition $[42,43]$. The habitat in which it grows affects its chemical composition and thus the medicinal value of the plant $[36,44]$. The components that can be distinguished in the chemical composition of the species include specific sesquiterpene lactones, essential oil with monoand sesquiterpenes, flavonoids, coumarins, phenolic acids [36], tannins, saponins [45], polyalkenes [18], phytosterols, fatty acids [45], and proteins, including enzyme proteins ( $\bullet$ Tables 1 and 2 ) [45].

The compounds that are of significance for the plant's activity profile are sesquiterpene lactones. The most important compound in this group is artemisinin ( $\bullet$ Fig. 1 ), which accumulates in its glandular hairs situated on both the leaves and flowers of the plant $[31,36,45,70]$. Its concentration in $A$. annua leaves ranges from 0.01 to $1.50 \%$ dry weight. The discoverer of artemisinin was a Chinese female specialist in pharmaceutical chemistry, Prof. Youyou Tu, who, for this achievement and proving the effectiveness of this compound in the treatment of malaria, was awarded the 2015 Nobel Prize in Medicine [1,71]. Artemisinin has a characteristic peroxide bridge, which determines its mode of action $[38,45,72,73]$. After extracting artemisinin, the compound is used to produce the semisynthetic derivatives artemether, artesunate, dihydroartemisinin, and arteether [18]. Artesunate is obtained by reducing artemisinin. After administration, this compound is transformed into the active form, dihydroartemisinin, which is the most readily soluble in water, and thus translates into its relatively high bioavailability. Artemether is also metabolized to dihydroartemisinin, but to a lesser extent [74]. Apart from artemisinin, other sesquiterpenes are specific components of $A$. annua, including isomers of artemisinin, artemisinic acid, artemisinol, and epoxyartemisinic acid $[6,50]$.

The concentration of essential oil in the plant varies between 1.4 and $4.0 \%$ [18]. The oil is rich in terpenes, and its main components are camphene, Artemisia ketone, camphor, $\beta$-caryophyllene, and $\beta$-pinene ( $\triangleright$ Fig. 2). Germakrene D, borneol, and cuminal are also present in high concentrations $[18,42,43,46,47,62,64,67$, 68]

The most frequently listed flavonoids characteristic of the species are artemetin and casticin ( $\bullet$ Fig. 3 ) [36, 46, 51, 52]. Other flavonoid compounds are derivatives of apigenin, luteolin, quercetin, kaempferol, and isorhamnetin [17]. Quercetin and kaempferol derivatives account for $84.8 \%$ of all the polyphenols [53]. Among the coumarins, cis- and trans-melilotoside, esculetin, isofraxidine, coumarin, tomentin, scopoletin, and scopolin can be distinguished [17, 52, 59].

It has also been proven that $A$. annua is a plant rich in quinic acid and its derivatives, and also in phenolic acids, including chlorogenic acid and its derivatives, as well as caffeic acid and rosmarinic acid [46, 52-54].

\section{Importance in the History of Asian Medicine}

Little known in Europe, A. annua L. has been used in traditional Chinese medicine (TCM) as a plant-derived antipyretic and antimalarial drug for over 2000 years. Artemisinin, isolated from this plant (in Chinese - Huang hua hao, or Qing Hao) in the 1970s, has become an effective drug in cases of drug-resistant malaria (resistance to quinine and chloroquine) in European pharmacology [75].

The oldest information in the Chinese medical literature regarding the therapeutic use of $A$. annua $\mathrm{L}$. comes from a treatise written about 200 BC on a piece of silk that was excavated in 1973 from the grave of Ma-wang-tui. The treatise, named by Chinese researchers as Prescriptions for 52 diseases (Wu Shi Er Bing Fang), is one of the oldest sources of knowledge on the tradition of Chinese pharmaceutical technology. It describes 224 medicines and methods of their preparation [76], with annual mugwort (called qinghao or qui) described as a medicine for haemorrhoids (fumigant) [77]. Among herbal medicines, the plant is also mentioned in later medical works, for example, Shen Nong Ben Cao jing (Shen Nong's Herbal Classic), Da guan Ben Cao (Grand Materia Medica), and Ben Cao Gang Mu (Compendium of Materia Medica) [33].

A. annua (in Chinese qinghao or Qing $\mathrm{Hao}$ ) was first described as an herbal medicine against malaria by Hong Ge (284-363 AD), a physician of the Eastern Jin Dynasty (317-420 AD) in Zhou Hou Bei Ji Fang (A Handbook of Prescriptions for Emergency). The known recipes included Qing Hao pills, Qing Hao decoction or drink, Qing Hao powder, Qing Hao infusion, Qing Hao drops, and Qing Hao wine. For example, the decoction of Qing Hao is also mentioned in Sheng ji Zong Lu (General Medical Collection of Royal Benevolence), an encyclopaedic collection of prescriptions written during the Song Dynasty (960-1279 AD), and the pills, Jie Nue Qing Hao, in Dan Xi Xin Fa (Danxi' Mastery of Medicine) during the Yuan Dynasty 
- Table 1 Chemical composition of A. annua.

\begin{tabular}{|c|c|c|}
\hline Group of compounds & Compounds & References \\
\hline \multirow{3}{*}{$\begin{array}{l}\text { Sesquiterpene lac- } \\
\text { tones }\end{array}$} & artannuin B & {$[30,36,46]$} \\
\hline & artemisinin & {$[18,36,46-49]$} \\
\hline & artemisinic acid & {$[36,46-48]$} \\
\hline \multirow[t]{2}{*}{ Sesquiterpenes } & artemisinol, artemisinin I, II, III, IV, V, artemisinin isomers, epoxyartennuic acid & {$[6,50]$} \\
\hline & dihydroartemisic acid & {$[46,48]$} \\
\hline \multirow[t]{20}{*}{ Flavonoids } & artemetin, casticin & {$[36,46,51,52]$} \\
\hline & $\begin{array}{l}\text { 3,5-dihydroxy-3',4',6,7-tetramethoxyflavone, quercetin 3-glucoside, acacetin, apigenin, } \\
\text { astragalin, chrysoeriol, chrysosplenol C, chrysin, cinaroside, 3,4'-dimethyl-quercetagentin ether, } \\
\text { 3-methyl-quercetin ether, 7-methyl-luteolin ether, } \\
\text { eupatin, 3-methoxy-kaempferol glucoside, } \\
\text { marnsetin glucoside, isorhamnetin, kirsiliol, kirsimaritin, quercimeritin, laricitrin, marnsetin, } \\
\text { micanine, retina, syringetin, tamarixetine }\end{array}$ & {$[36,46,51,52]$} \\
\hline & $\begin{array}{l}\text { 3,5-di-hydroxy-6,3',4'-tetramethoxyflavone, 3,5-di-hydroxy-6,7,4'-trimethoxyflavone, } \\
\text { 3,5-di-methoxyquercetagentin, quercetin 3-O-galactoside, isorhamnetin 3-O-glucoside, } \\
\text { 3-O-glucoside of kaempferol, 3-O-glucoside of quercetin, 3-O-hexoside of marnsetin, } \\
\text { 3-O-methylquercetagentin, 7-O-glucoside of diosmetin, 8-methoxykaempferol, kaempferol }\end{array}$ & [53] \\
\hline & $\begin{array}{l}\text { apigenin 6-C-arabinosyl-8-C-glucoside, apigenin 6-C-glucosyl-8-C-arabinoside, patulentin } \\
\text { glucoside, jaceidin, chrysoeriol rutinoside, vitexin, }\end{array}$ & {$[54]$} \\
\hline & luteolin 7-O-glucoside & {$[53,54]$} \\
\hline & chrysosplenol D & {$[36,46,52,55,56]$} \\
\hline & chrysosplentin & {$[36,46,52,57]$} \\
\hline & di-hydroartemisinin & [58] \\
\hline & eupatorine & {$[36,46,52]$} \\
\hline & isoquercetin & [59] \\
\hline & isovitexin & {$[46,54]$} \\
\hline & kaempferol & {$[46,52]$} \\
\hline & cirsilineol & {$[36,46,52,54]$} \\
\hline & quercetin & {$[46,52,53]$} \\
\hline & luteolin & {$[46,52,53]$} \\
\hline & myrcetin & {$[56]$} \\
\hline & myricetin & {$[46]$} \\
\hline & $\begin{array}{l}\text { apigenin derivatives, isorhamnetin derivatives, kaempferol derivatives, quercetin derivatives, } \\
\text { luteolin derivatives }\end{array}$ & {$[60,61]$} \\
\hline & rhamnetine & {$[31,56]$} \\
\hline & rutoside & {$[17,46,52]$} \\
\hline \multirow[t]{4}{*}{ Coumarins } & cis-melilotoside, trans-melilotoside & {$[17,52,59]$} \\
\hline & esculetin, isofraxidine, coumarin, tomentin & [52] \\
\hline & scopoletin & {$[52,57]$} \\
\hline & scopolin & {$[17,52]$} \\
\hline \multirow[t]{6}{*}{ Phenolic acids } & $\begin{array}{l}\text { 3,4-diferuloquinic acid, 3,4-di-caffeoylquinic acid, 3,5-diferuloquinic acid, 3,5-di-caffeoylquinic } \\
\text { acid, 3,5-di-O-caffeoylquinic acid, 3,5-caffeoyletherquinic acid, 3-feruloquinic acid, 3-caffeoyl- } \\
\text { quinic acid, 4,5-diferuloquinic acid, 4,5-di-O-caffeoylquinic acid, 4-feruloquinic acid, 4-caffeoyl- } \\
\text { 3,5-di-succinylquinic acid, 4-caffeoylquinic acid, 5-feruloquinic acid }\end{array}$ & {$[54]$} \\
\hline & chlorogenic acid & {$[46,52-54]$} \\
\hline & diferulcaffeoylquinic acid, ferulic acid & [53] \\
\hline & caffeic acid & {$[53,54]$} \\
\hline & coumaric acid & {$[52]$} \\
\hline & rosmarinic acid & {$[46,59]$} \\
\hline Phenols & syringaldehyde & continued \\
\hline
\end{tabular}


- Table 1 Continued

\begin{tabular}{|c|c|c|}
\hline Group of compounds & Compounds & References \\
\hline Saponins & n.d. & {$[45]$} \\
\hline Tannins & n.d. & {$[45,62]$} \\
\hline Sterols & $\beta$-sitosterol, stigmasterol & {$[63]$} \\
\hline Polyalkenes & n.d. & [18] \\
\hline Fatty acids & palmitic acid & {$[64]$} \\
\hline Organic acids & quinic acid & {$[52,54]$} \\
\hline Polysaccharides & polyuronides & {$[62]$} \\
\hline Enzymes & $\beta$-glucosidase, $\beta$-galactosidase & {$[65]$} \\
\hline Proteins & n.d. & {$[45]$} \\
\hline Vitamins & vitamins $\mathrm{A}$ and $\mathrm{E}$ & {$[66]$} \\
\hline
\end{tabular}

(1271-1368 AD). A. annua L. was recommended for paroxysmal malarial fever by the physician Shizhen Li (1518-1593) in his book Ben Cao Gang Mu (Compendium of Materia Medica). This plant, in Chinese medical literature, was given the binominal Latin name Artemisia annua only in the 20th century with the publication of the First Chinese Pharmacopoeia (Chung-hua yao-tien) in 1930 [76, 78]. In herbal medicine of the West, this plant had been given virtually no attention until the early 20th century.

Analysing historical Chinese medical works (from $2000 \mathrm{BC}$ to 640 AD) in search of an effective cure for malaria, Prof. Youyou Tu from the Academy of Traditional Chinese Medicine at the Ministry of Health of China (now China Academy of Chinese Medical Sciences) has collected over 2000 recipes for medicines of plant, animal, and mineral origin, publishing them in the brochure Antimalarial Collections of Recipes and Prescriptions (Kang Nue Dan Mi Yan Fang Ji). In her research, conducted with her team since 1969, the researcher has relied on the textbook by Hong Ge from the 4th century, Zhou Hou Bei Ji Fang (A Handbook of Prescriptions for Emergencies), in which he reported that Qing Hao relieved the symptoms of malaria [33]. In 1971, the outcome of the experiments conducted by Youyou Tu's team was obtaining a mugwort extract (the extract was called Qinghaosu), and a year later the discovery that it contained an organic chemical compound called artemisinin, which has found application in the treatment of malaria. For her discoveries, in 2011, Youyou Tu received the Lasker-DeBakey Clinical Medical Research Award, and in 2015 the Nobel Prize in Physiology or Medicine [79].

\section{Applications in Traditional Asian Medicine}

Traditional medicine in China and India makes use of all the parts of the plant, the flowers, leaves, stem, seeds, and essential oil. They are used to treat jaundice, bacterial dysentery, and fever $[18,80]$.

In China, A. annua has been used for over 2000 years as an antipyretic for malarial fever, tuberculosis, and, in TCM, for "fever caused by summer heat" and for "afternoon fever associated with yin deficiency" $[8,29]$. A. annua is also known as a remedy for bleeding wounds and haemorrhoids [29]. In TCM, it is also recommended to use the plant in the treatment of tumours, to fight infections caused by protozoa from the genera Plasmodium, Acanthamoeba, Schistosoma, Leishmania, to fight viral diseases (e.g., AIDS and hepatitis B), and to treat bacterial infections [5, 29]. In TCM, A. annua is also recommended for autoimmune diseases such as systemic lupus erythematosus and rheumatoid arthritis [81]. A. annua seed extracts can be used to treat eye diseases $[29,82]$. The plant is traditionally used in the form of infusions, aqueous extracts, and tinctures from the dried herb [17, 83].

\section{Applications in Modern Phytotherapy and Position in Official Pan-World Medicine}

A. annua has an established position in the treatment of malaria [18]. It is a valuable source of artemisinin [29], which is effective in the early stages of trophozoite malaria. It also inhibits the growth of Plasmodium schizonts and has a gametocytocidal effect, which limits the spread of the protozoan to mosquitoes [18]. Its semisynthetic derivatives artemether, artesunate, and dihydroartemisinin are also used in the treatment of malaria [84].

A growing problem in the treatment of malaria is the developing resistance of Plasmodium species to antimalarial drugs, including artemisinin [85]. A combined therapy, Artemisinin Combination Therapy (ACT), has become a way to reduce resistance. It is based on combining artemisinin with antimalarial drugs with a different mechanism of action that works longer [86]. The most commonly used combinations are artemether with lumefantrine, artesunate with amodiaquine, artesunate with mefloquine, artesunate with sulfadoxine and pyrimethamine, and dihydroartemisinin with piperaquine [84].

The likely causes of the increasing resistance to artemisinin are the uncontrolled use of ACT therapy, the use of subtherapeutic doses of artemisinin, the use of artemisinin derivatives as prophylactic agents, and the use of substandard or counterfeit drugs [85].

Medicines based on $A$. annua constitute standardized extracts in the form of tablets and injections $[38,72]$. When preparing 
- Table 2 Chemical composition of A. annua essential oil.

\section{Group of compounds}

References

Monoterpenes

1,8-Cineole

4-Terpineol, sabinene

Artemisinin alcohol

Santolin alcohol, cis-chrysanthenol, dehydro-1,8-cineol, dehydrosabinene, myrtenal, cis-pinocarveol acetate, p-mentha-2,4 (8) -diene, $\delta$-terpineol

Yomogi alcohol

Artemisiatrien, cis- $\beta$-O-cymene, bornyl acetate, piperitone, terpinolene, $\alpha$-felandrene, $\alpha$-thujone

Borneol

cis-Carveol, carvone, myrtenyl acetate, $p$-cymene, trans-carveol, trans- $\beta$-O-cymene, thujen, verbenol,

verbenone, $\alpha$-terpinolene

Dehydrosabinaketone, $\beta$-pinene oxide

Eugenol

cis-Sabinene hydrate

trans-Sabinene hydrate, $\alpha$-campholenal

Ipsdienol, myrcenol, neryl acetate

Camphene

Camphor

Artemisinin ketone

Cuminal

Limonene

Linalool

Myrcene

Myrtenol

Pinocarvone, trans-pinocarveol

Santolinatriene, $\alpha$-terpinene

$\alpha$-Pinene

$\alpha$-Terpineol

$\alpha$-Thujene, $\gamma$-terpinene

$\beta$-Pinene

$[18,42,43,46,47,62,64,67,68]$

$[42,43,64,67,68]$

$[30,42,67,68]$

[68]

[42, 67-69]

[43]

$[18,42,43,47,62,64,68]$

[42]

[67]

$[42,43]$

$[43,67,68]$

$[42,68]$

[64]

$[18,42,43,47,64,67,68]$

$[18,42,43,47,64,67,68]$

$[18,30,42,67,68]$

[7]

[46]

$[18,42]$

$[18,42,43,64,67]$

$[42,64,67]$

$[67,68]$

$[42,43,67,68]$

$[18,42,43,46,47,64,67,68]$

$[42,64,67,68]$

$[64,68]$

$[18,42,43,64,67,68]$

\section{Sescquiterpenes}

(-) - Isolongifolen-9-one, cis- $\beta$-caryophyllene, epi- $\alpha$-cadinol, humulene, cubenol, nootkaton, spathulenol, trans- $\beta$-caryophyllene, $\beta$-chamigrene, $\beta$-gurjunene, $\gamma$-gurjunen, $\beta$-cadinene, $\gamma$-cadinene

Aristolon, cis-cadin-4-en-7-ol, germacren A, selin-11-en-ol isomer, selin-3,11-dien-6 $\alpha$-ol, $\alpha$-humulene, $\beta$-bourbonene, $\beta$-elemen, $\beta$-cubeben

Bicyclogermacrene

trans- $\beta$-Farnesane

Germacren B, kopaene, $\alpha$-farnesan, $\gamma$-elemen

Germacren D

Isoledene, trans-beta-kopaene

Caryophyllene, $\alpha$-longipinene

Cubeben

Nerolidol

Caryophyllene oxide

$\alpha$-Copaene

$\beta$-Caryophyllene

$\beta$-Selinene

[42]

[68]

$[43,67,68]$

$[67,68]$

[64]

$[42,43,47,64,67,68]$

[62]

[43]

$[42,68]$

[46]

$[42,64,68]$

$[42,43,67,68]$

$[18,67,68]$

$[42,43,68]$ 
- Table 2 Continued

\begin{tabular}{|l|l|}
\hline Group of compounds & References \\
\hline$\gamma$-Muurolene & {$[42,43]$} \\
\hline$\delta$-Cadinene & {$[43,68]$} \\
\hline Diterpenes & {$[43]$} \\
\hline Vulgarone & {$[64]$} \\
\hline Other volatile compounds & {$[67]$} \\
\hline Nonanal & {$[42]$} \\
\hline Isovalerate hexanoate & {$[42,68]$} \\
\hline cis-Jasmon, benzyl benzoate, eudesm-7(11)-en-4-ol, hexanal, arteannuic acid & {$[68]$} \\
\hline Ethyl 2-methylbutanoate, propyl 2-methylbutanoate & {$[62]$} \\
\hline 1-Dodekene, 2-hexenyl 2-methylbutanoate, cis-2-hexenyl 3-methylbutanoate, 2-methyl-2-butenyl \\
\hline 3-methylbutanoate, 3-methyl-3-butenyl 3-methylbutanoate, benzyl 3-methylbutanacetate, nonadecane
\end{tabular}

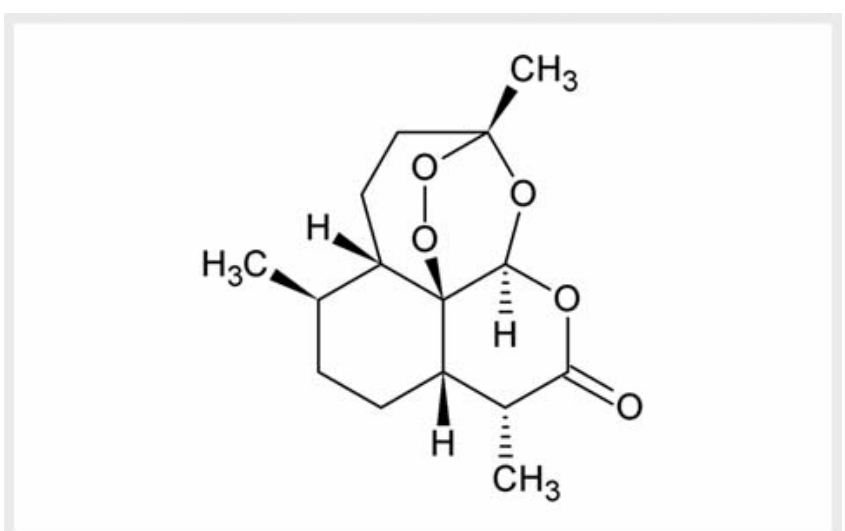

- Fig. 1 Chemical structure of the sesquiterpene lactone artemisinin.

preparations from $A$. annua leaves, or an infusion with artemisinin, one should remember not to use metal objects because artemisinin reacts with iron. In the case of infusion, it has been proven that it is more effective to pour boiling water over the leaves than to add them to boiling water [80].

The raw material is the dried leaves of A. annua, Artemisia annuae folium. It has a monograph in the Chinese Pharmacopoeia and the Vietnamese Pharmacopoeia $[15,16]$. According to these documents, the leaves should be standardized for artemisinin content, which cannot be lower than $0.7 \%$ of dry weight. The indications for the use of the raw material given in the Chinese Pharmacopoeia are fever of various origins and malaria [8]. It is also used for gastrointestinal complaints and skin diseases [2]. The International Pharmacopoeia, published by the WHO, also specifies the dried A. annua, Artemisiae annuae herba, as a raw material [8]. The species does not have a monograph in European Pharmacopoeia. The most important scientifically proven pharmacological properties of $A$. annua are described below and presented in the $>$ Table 3.

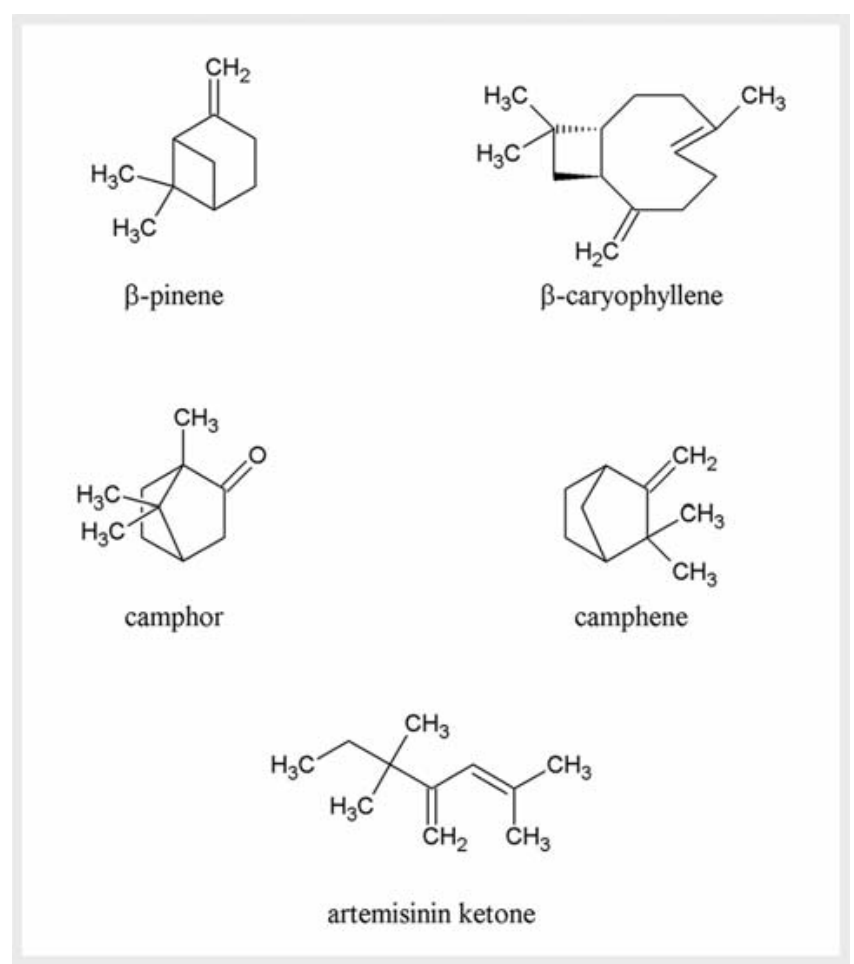

- Fig. 2 Chemical structure of volatile compounds characteristic of the essential oil from $A$. annua herb.

\section{Biological Activity Confirmed by Scientific Research}

\section{Antimalarial activity}

As part of the collaboration of scientists from the German Institute for Medical Mission, the University of Tübingen in Tübingen (Germany) and from Inspection Provinciale de la Santé Publique in Bukavu (Congo), an open, randomized, clinical trial was conducted in which patients with uncomplicated malaria caused by 
<smiles>COC1=C(O)c2c(cc(OC)c(OC)c2O)OC1c1ccc(OC)c(OC)c1</smiles>

artemetin<smiles>COc1ccc(-c2oc3cc(OC)c(OC)c(O)c3c(=O)c2OC)cc1O</smiles>

casticin

- Fig. 3 Chemical structure of flavonoids characteristic of $A$. annua.

infection with Plasmodium falciparum were administered an infusion of $A$. annua herb in various doses. After 7 days of therapy, the percentage of cured patients was $74 \%$ compared to $91 \%$ for the control group treated with quinine [87].

Other trials confirming the antimalarial action of the compounds contained in $A$. annua leaf extracts were conducted as part of the collaboration between the Université d'Abomey Calavi in Cotonou (Benin), Université Catholique de Louvain in Brussels (Belgium), and Université de Liège in Liège (Belgium). Using aqueous and hydro-ethanolic extracts from $A$. annua leaves, tests were performed in vivo against Plasmodium berghei and in vitro against $P$. falciparum. In the in vivo study, extracts from the plant were administered for 4 days to mice infected with $P$. berghei. The in vitro study was carried out using the lactate dehydrogenase of the plasmodium, whose activity was tested. In the positive control, artemisinin was used in both experiments. The results of the in vitro study proved that the effects of both extracts were similar to those of pure artemisinin at the same dose. In the in vivo study, the hydro-ethanolic extract of $A$. annua containing $20 \mathrm{mg} / \mathrm{kg}$ of artemisinin was more effective than the aqueous extract and pure artemisinin at a dose of $140 \mathrm{mg} / \mathrm{kg}$. The effectiveness of the aqueous extract containing $20 \mathrm{mg} / \mathrm{kg}$ of artemisinin was the same as that of pure artemisinin at a dose of $140 \mathrm{mg} / \mathrm{kg}$. The obtained results indicate the importance of the presence of other $A$. annua components that increase artemisinin activity [88].

The effect of an infusion of $A$. annua leaves on in vitro cultures of $P$. falciparum (chloroquine-resistant and chloroquine-sensitive strains) was studied at the University of Salento and Lachifarma in Lecce (Italy). The method used was the lactate dehydrogenase test. The infusion of $A$. annua leaves was also analysed for the concentration of artemisinin. The study showed that infusions from the plant had antimalarial effects. However, the amounts of artemisinin present in the infusions were too low to be responsible for the effect. It was concluded that the effectiveness of infusions against $P$. falciparum was determined by the synergistic effect of artemisinin with other compounds contained in $A$. annua leaves [55].

The likely mechanism of action of $A$. annua is interference of plant components with protein metabolism, and interference with the mitochondrial activity of protozoa of Plasmodium spp. [72]. Another more precisely described mechanism of action speaks of artemisinin-assisted inhibition of the calcium pump that is necessary for the synthesis of proteins of the plasmodium cell membrane. Artemisinin connects to the calcium pump, exposing its peroxide bridge. The peroxide bridge opens under the influence of iron present in the mitochondria. The iron attracts an oxygen electron, and the activated oxygen attracts hydrogen atoms nearby. As a result, radicals are created that attack organic carbon-based structures. The whole process leads to the inactivation of the pump and death of the protozoan [89].

$P$. falciparum requires mitochondrial activity during its life cycle to keep its respiratory chain active. During treatment with artemisinin, after contact with the iron present in mitochondria, this compound was activated. Oxygen atoms disrupt the electron transport chain of the plasmodium and lead to the depolarization of the mitochondrial membrane. This prevents the biosynthesis of pyrimidine, which causes the death of the protozoan [18]. Activated artemisinin also has the ability to inhibit inflammation caused by the presence of protozoa adhering to the endothelium of the capillary vessels [72]. The artemisinin derivatives artemether, artesunate, and their active metabolite dihydroartemisinin do not affect tissue forms of Plasmodium and are not used in the prevention of malaria $[74,86]$.

\section{Action against other diseases caused by protozoa}

A group of Polish researchers from the Poznań University of Medical Sciences in Poznań (Poland) has investigated whether extracts from $A$. annua herb and pure artemisinin can be used against acanthamebiasis, a parasitic disease caused by the protozoan Acanthamoeba castellanii. Extracts were obtained using various solvents, such as water, methanol, and chloroform. The in vivo study was conducted by giving the prepared extracts to mice infected with $A$. castellanii, while in the in vitro study, amoebas were cultured on agar with filter paper saturated with various $A$. annua extracts or artemisinin. The results of the experiments showed that the extracts from $A$. annua had strong lethal properties against $A$. castellani in both the in vivo and in vitro models. In the experiment on animals, an extension of rodent life was observed, while in the in vitro experiment, the use of pure artemisinin was the most effective, followed by extracts with methanol, chloroform, and water [95].

The activity of $A$. annua leaf and seed extracts in the treatment of leishmaniasis has been tested at Indian research centres: Hamdard University and the International Centre for Genetic Engi- 
- Table 3 Pharmacological properties of $A$. annua.

\begin{tabular}{|c|c|c|}
\hline Activity & Mechanism of action & References \\
\hline \multirow[t]{6}{*}{ Antimalarial } & $\begin{array}{l}\text { Improvement of malaria symptoms after treating patients with infusion of } A \text {. annua herb. Inactivation of the } \\
\text { protozoan calcium pump. }\end{array}$ & [87] \\
\hline & Lethal activity of hydro-ethanolic and aqueous extracts from $A$. annua leaves against $P$. falciparum and $P$. berghei. & {$[88]$} \\
\hline & Interference of artemisinin with protein metabolism and mitochondrial activity of Plasmodium spp. protozoa. & {$[72]$} \\
\hline & Inhibition of the plasmodium calcium pump. & {$[89]$} \\
\hline & $\begin{array}{l}\text { Depolarization of the mitochondrial membrane of Plasmodium spp. protozoa and inhibition of pyrimidine } \\
\text { biosynthesis. }\end{array}$ & {$[38]$} \\
\hline & Synergism of action of artemisinin and other compounds contained in $A$. annua leaves against $P$. falciparum. & {$[55]$} \\
\hline \multirow{2}{*}{$\begin{array}{l}\text { Against other } \\
\text { diseases caused } \\
\text { by protozoa }\end{array}$} & $\begin{array}{l}\text { Lethal activity against } A \text {. castellani of artemisinin and methanolic, ethanolic, and aqueous extracts from } \\
\text { A. annua herb. }\end{array}$ & {$[34]$} \\
\hline & $\begin{array}{l}\text { Compounds contained in } A \text {. annua seed and leaf extracts have lethal activity against } L \text {. donovani. } \\
\text { The mechanism of action is to direct protozoan cells towards apoptosis. }\end{array}$ & {$[90]$} \\
\hline \multirow{4}{*}{$\begin{array}{l}\text { Antibacterial and } \\
\text { antifungal }\end{array}$} & Lethal activity of $A$. annua leaf extracts against $E$. coli. & {$[44]$} \\
\hline & $\begin{array}{l}\text { Lethal activity of essential oil and 1,8-cineol, camphor, and artemisia ketone isolated from A. annua herb against } \\
\text { E. coli, S. enteritidis, S. typhi, Y. enterocolitica, and L. monocytogenes. Components of essential oil penetrate } \\
\text { through the bacterial cell membrane, causing cellular dysfunction, increasing permeability of bacterial mem- } \\
\text { brane and components. }\end{array}$ & {$[67]$} \\
\hline & $\begin{array}{l}\text { Essential oil inhibits growth of bacteria: S. aureus, B. subtilis, E. faecalis, P. aeruginosa, E. coli, K. pneumoniae, } \\
\text { A. baumannii, and fungi: C. famata, C. utilis, and C. albicans, and also inhibits cell adhesion and reduces the } \\
\text { expression of virulence factors. }\end{array}$ & {$[42]$} \\
\hline & $\begin{array}{l}\text { Low and moderate inhibition of growth of bacteria: S. aureus, B. cereus, S. lutea, S. enteritidis, K. pneumoniae, } \\
\text { E. coli, Shigella, and fungi: C. albicans and A. fumigatus. }\end{array}$ & {$[68]$} \\
\hline \multirow[t]{2}{*}{$\begin{array}{l}\text { Immuno- } \\
\text { suppressive }\end{array}$} & $\begin{array}{l}\text { Inhibition of lymphocyte proliferation and reduction of } \mathrm{IgG}, \operatorname{lgG} 1 \text {, and } \mathrm{lgG} 2 \mathrm{~b} \text { antibody levels after administra- } \\
\text { tion of } A \text {. annua whole plant extract. }\end{array}$ & {$[81]$} \\
\hline & $\begin{array}{l}\text { Artemisinin obtained from } A \text {. annua inhibits late-type hypersensitivity response and has a suppressive effect } \\
\text { on calmodulin responsible for activation of T lymphocytes. }\end{array}$ & {$[91]$} \\
\hline \multirow[t]{2}{*}{ Anti-inflammatory } & Reduction of pain and stiffness in joints and improvement of mobility after using $A$. annua extract. & {$[92]$} \\
\hline & $\begin{array}{l}\text { Use of aqueous extracts from } A \text {. annua leaves reduces secretion of proinflammatory cytokines, interleukin-8, } \\
\text { and interleukin-6. Rosmarinic acid is largely responsible for this effect. }\end{array}$ & {$[59]$} \\
\hline Analgesic & $\begin{array}{l}\text { Giving mice essential oil from } A \text {. annua herb, camphor, 1,8-cineol, and } \alpha \text {-pinene reduces writhing episodes } \\
\text { caused by acetic acid. }\end{array}$ & {$[68]$} \\
\hline \multirow[t]{3}{*}{ Antioxidant } & $\begin{array}{l}\text { Methanolic extracts from } A \text {. annua leaves have the highest concentration of phenolic and flavonoid compounds } \\
\text { showing a reducing effect. }\end{array}$ & [93] \\
\hline & Reducing activity of $A$. annua leaf extracts in DPPH test. & {$[44]$} \\
\hline & $\begin{array}{l}\text { Essential oil from } A \text {. annua herb and its components: 1,8-cineol, artemisia ketone, and } \alpha \text {-pinene show weak } \\
\text { reducing activity in tests with DPPH, ABTS radical, and hydrogen peroxide. }\end{array}$ & {$[68]$} \\
\hline Nephroprotective & Administration of $A$. annua essential oil to rats exposed to carbon tetrachloride prevents kidney damage. & {$[68]$} \\
\hline \multirow[t]{4}{*}{ Cytotoxic } & $\begin{array}{l}\text { Polyphenols contained in } A \text {. annua inhibit adhesion of cancer cells to endothelial cells and inhibit epithelial- } \\
\text { mesenchymal transition. }\end{array}$ & {$[53]$} \\
\hline & $\begin{array}{l}\text { Regression of prostate cancer in patients treated with capsules containing a concentrate with } A \text {. annua and } \\
\text { bicalutamide. }\end{array}$ & {$[94]$} \\
\hline & Inhibiting proliferation of human osteosarcoma cells and directing them towards apoptosis. & {$[58]$} \\
\hline & $\begin{array}{l}\text { Methanolic extract from A. annua leaves collected in Egypt showed significant cytotoxic activity against MCF7 } \\
\text { human breast adenocarcinoma cell line, human lung cancer cell line, and Chinese hamster ovary CHO cell line. }\end{array}$ & [44] \\
\hline \multirow[t]{2}{*}{$\begin{array}{l}\text { Auxiliary action in } \\
\text { obesity treatment }\end{array}$} & $\begin{array}{l}\text { Reduction of fat droplet accumulation and inhibition of PPAR } \gamma, C / E B P \alpha, \text { SREBP-1c, FAS, and ACC protein } \\
\text { expression under the influence of } A \text {. annua essential oil. }\end{array}$ & {$[43]$} \\
\hline & $\begin{array}{l}\text { Reduction of insulin resistance, reduction of liver steatosis and fibrosis. Lowering the levels of SREBP-1c, ChREBP, } \\
\text { COX-2. Inhibition of TGF- } \beta 1 \text { and connective tissue growth factor. }\end{array}$ & {$[36]$} \\
\hline Anthelmintic & $\begin{array}{l}\text { Extracts from } A \text {. annua leaves inhibit growth of larvae and hatching of eggs of } H \text {. contortus (parasite of sheep } \\
\text { and goats). }\end{array}$ & [17] \\
\hline
\end{tabular}


neering and Biotechnology in New Delhi, and the Institute of Nuclear Medicine and Allied Sciences in Delhi. The extracts were obtained by extraction with $n$-hexane, ethanol, and water. To evaluate the antiprotozoal activity, the amastigote and promastigote forms of Leishmania donovani were treated with the extracts. The researchers demonstrated significant lethal activity against both forms of the protozoan. The authors of the study report that the mechanism of action of the extracts consists in directing protozoan cells towards apoptosis [90].

\section{Antibacterial and antifungal activities}

At King Abdullah University of Science and Technology in Thuwal (Saudi Arabia), Research and Development, Qatar Foundation in Doha (Qatar), and at Kuwait University in Kuwait City (Kuwait), tests were conducted on the antibacterial activity of $A$. annua leaf extracts. The experiments were performed by the disk diffusion method against the bacteria Escherichia coli. The extraction of A. annua leaves collected in Jericho and Egypt was carried out with hexane, chloroform, methanol, and water. It was proven that the origin of the plant material had an influence on the strength of the antibacterial effect. The highest activity was proven for aqueous extracts of the plants collected in Jericho. Other tested extracts showed a lesser effect. None of the extracts of the plants from Egypt showed antibacterial activity [44].

Researchers from the University of Florence in Florence and Sesto Fiorentino and from the University of Pisa in Pisa (Italy) have investigated the activity of $A$. annua components against $E$. coli, Salmonella enteritidis, Salmonella typhi, Yersinia enterocolitica, and Listeria monocytogenes. Employing the disc diffusion method, they used essential oil obtained from the blooming $A$. annua herb and selected oil components (1.8-cineol, camphor and artemisia ketone). All the microorganisms tested were found to be sensitive to the essential oil and its components. In addition, $Y$. enterocolitica strains were more sensitive to $A$. annua herb oil than to the positive control - amoxicillin. It was also found that the essential oil was less effective than 1.8-cineol against S. typhi. The mechanism of action reported by the authors of the study was the penetration by essential oil components through the cell membrane into the interior of the bacteria, which causes cell dysfunction, increased membrane permeability, and outflow of ions with other components [67].

In 2015, at the University of Bucharest in Bucharest (Romania), the disc diffusion method was used to examine the effect of the essential oil of $A$. annua herb on the bacteria Staphylococcus aureus, Bacillus subtilis, Enterococcus faecalis, Pseudomonas aeruginosa, E. coli, Klebsiella pneumoniae, and Acinetobacter baumannii and the fungi Candida famata, Candida utilis, and Candida albicans. The tested strains were found to be sensitive to the essential oil. The measured MIC values ranged from $0.51 \mathrm{mg} / \mathrm{mL}$ for $E$. faecalis to $16.3 \mathrm{mg} / \mathrm{mL}$ for $E$. coli and Klebsiella pneumoniae. The essential oil also inhibited the adhesion of microbial cells to an inert medium and inhibited the expression of hemolysin, gelatinase, deoxyribonuclease, lipases, and lecithinase, which are virulence factors that promote the penetration by microorganisms into the host organism [42].

Another research group from the University of Niš in Niš (Serbia), using the microdilution method on titration plates, also tested the antibacterial and antifungal effects of the essential oil from $A$. annua herb. The tests were performed on the bacteria S. aureus, Bacillus cereus, Sarina lutea, Salmonella enteritidis, K. pneumoniae, E. coli, and Shigella spp. and the fungi C. albicans and Aspergillus fumigatus. These microorganisms were found to have low or moderate sensitivity to the essential oil. The highest susceptibility to $A$. annua essential oil was shown by the bacteria S. lutea, for which the MIC value was $2.5 \mathrm{mg} / \mathrm{mL}$ [68].

\section{Immunosuppressive effect}

Researchers at Zhejiang University and The Hospital of Zhejiang University in Hangzhou (China) have investigated an ethanolic extract of $A$. annua herb for immunosuppressive activity. The tests were carried out both in vitro and in vivo. In the in vitro study, they induced proliferation of lymphocytes isolated from mouse spleens with concanavalin $A$ and lipopolysaccharide and assessed immunosuppression after administering the $A$. annua extract. The in vivo study involved immunizing mice with ovalbumin and, after administration of the plant extract, examining the suppression of specific antibodies and the suppression of the proliferation of splenic lymphocytes. After administering the $A$. annua extract, inhibition of lymphocyte division in a concentration-dependent manner was observed in both experiments. The study with rodents demonstrated a reduction in the levels of $\mathrm{ggG}, \mathrm{IgG} 1$, and $\mathrm{IgG} 2 \mathrm{~b}$ in the serum. The results of the experiments justify the traditional use of $A$. annua in the treatment of autoimmune diseases [81].

Another study confirming the immunosuppressive activity of the species was conducted at Tarbiat Modarres University, Shahed University, and Shahid Beheshti University in Tehran (Iran). Artemisinin obtained from $A$. annua herb was used for the experiment to test whether the administration of the isolated compound to mice would inhibit the delayed-type hypersensitivity (DTH) immune response. Cyclosporin A was used as the control. Significant suppression of the DTH response was demonstrated over the course of the study. With the help of fluorescence spectroscopy, the in vitro study also proved the inhibitory effect of artemisinin on calmodulin, a regulatory protein activating $\mathrm{T}$ lymphocytes [91].

\section{Anti-inflammatory effect}

In 2015, a randomized, double-blind clinical trial was conducted at the University of Otago and Dunedin School of Medicine in Dunedin, and Promisia Integrative Limited in Wellington (New Zealand) that assessed the safety and anti-inflammatory effectiveness of an $A$. annua extract. The study was sponsored by Promisia Ltd., the company producing the preparation "Arthrem" containing $150 \mathrm{mg}$ of $A$. annua extract. The extract is obtained by extracting the herb of the plant using supercritical $\mathrm{CO}_{2}$. The preparation is recommended for pain and stiffness occurring in the course of osteoarthritis of the hip or knee joints. As part of the experiment, 42 patients were randomly assigned to three groups. Patients in the first group received "Arthrem" at a dose of $150 \mathrm{mg}$ of $A$. annua extract twice a day, those in the second group "Arthrem" at a dose of $300 \mathrm{mg}$ of $A$. annua extract twice a day, while patients in the third group constituted the control and received a placebo twice a day. The study lasted 12 weeks, and the 
effectiveness of the extract was assessed using the Western Ontario indicator, McMaster University of Osteoarthritis (WOMAC), and the visual analogue pain scale (VAS). Significant improvement in the WOMAC score was observed among the patients receiving the lower dose $(150 \mathrm{mg})$ of the extract. The patients declared improvement in physical fitness and reduction in joint stiffness, and on the VAS, a reduction in pain. The lower dose was also well tolerated. Using the higher dose of the extract $(300 \mathrm{mg})$, there was no significant improvement in the indicators tested. The authors of the study proved that a 3-month treatment with the $A$. annua extract $(150 \mathrm{mg})$ can reduce inflammation and have an analgesic effect in osteoarthritis [92].

Other studies were conducted at the Institut des Sciences de la Vie \& UCLouvain in Louvain-la-Neuve (Belgium) and CPQBA UNICAMP in Paulinia (Brazil). In the first stage, aqueous extracts were prepared from $A$. annua leaves. Then, their effect on Caco-2 cells (human colon adenoma cell line) was investigated [59]. Caco- 2 cells are able to form a brush border (microvilli) on the cell surface. They also have the ability to produce enzymes and systems that transport compounds from the intestinal lumen to the bloodstream [96]. In the study, the inflammation of Caco-2 cells was induced with cytokines and lipopolysaccharide. The effect of leaf extracts from the plant on the activity of cytochrome P450, which affects the metabolism of artemisinin, was also investigated. It was proven that the use of aqueous extracts from $A$. annua leaves reduced the secretion of proinflammatory cytokines, interleukin-8, and interleukin-6. This effect was attributed to the presence of rosmarinic acid in the extract. The extracts also inhibited calcitriol-induced activity of CYP3A4 and benz- $\alpha$-pyrene-induced activity of CYP1A1. The results indicate that extracts from $A$. annua leaves have an anti-inflammatory effect and can increase the bioavailability of artemisinin by inhibiting cytochrome P450 [59].

\section{Analgesic effect}

In 2013, the analgesic activity of essential oil obtained from A. annua herb was evaluated at the University of Niš in Niš (Serbia). For this purpose, a writhing test was performed using an animal model (mouse). The essential oil and some of its components (camphor, 1,8-cineol, and $\alpha$-pinene) were given to rodents separately. The writhing reflex was induced by the administration of acetic acid, which is used in studies of inflammatory peripheral pain. It was proven that all the tested compounds and the essential oil produced an analgesic effect that was dose dependent. At the highest tested dose of $400 \mathrm{mg} / \mathrm{kg}$, a $57 \%$ reduction in writhing episodes was recorded after administering the essential oil, a $64 \%$ reduction after administering camphor, a 54\% reduction after administering 1,8-cineol, and a 39\% reduction after administering $\alpha$-pinene [68].

\section{Antioxidant effect}

A study confirming the antioxidant properties of $A$. annua have been conducted at the University of Sargodha in Sargodha, University of Karachi in Karachi (Pakistan) and Universiti Putra Malaysia in Selangor (Malaysia). The extracts used for the experiment were obtained from A. annua leaves using hexane, chloroform, ethyl acetate, methanol, and water. The extracts were tested to determine which of them would be the most effective. The oxida- tion potential of individual extracts was assessed by estimating the total concentrations of phenols and flavonoids by determining the degree of lipid peroxidation, and by conducting the iron (III) reduction potential test (FRAP), DPPH radical scavenging activity test, and a test with vitamin $\mathrm{E}$ analogue, trolox, used to measure the total antioxidant potential of a mixture of antioxidant compounds (TEAC). The highest antioxidant activity was proven for the methanolic extract, while the aqueous extract was the weakest. The highest amounts of phenols $(134.5 \mathrm{mg} / \mathrm{g}$ of extract) and flavonoids $(615 \mathrm{mg} / 100 \mathrm{~g}$ of extract) were also extracted using methanol [93].

The DPPH test has also been performed at King Abdullah University of Science and Technology in Thuwal (Saudi Arabia), Research and Development, Qatar Foundation in Doha (Qatar) and at Kuwait University in Kuwait City (Kuwait). Leaves were collected from A. annua plants in Jericho and Egypt and extracted with hexane, chloroform, methanol, and water. The results of the study indicate that plants growing in Jericho have higher antioxidant activity, while extracts from plants collected in Egypt do not show any such activity [44].

Researchers at the University of Niš in Niš (Serbia) have also evaluated the antioxidant activity of the essential oil from A. annua herb and its components (1,8-cineol, artemisia ketone, and $\alpha$-pinene). A test involving DPPH and the ABTS radical was carried out, as well as a hydrogen peroxide scavenging test. Artemisia ketone and the essential oil proved to be the most active. The antioxidant potential of the oil and all the tested compounds was, however, significantly lower than the antioxidant potential of the control compounds - butylated hydroxytoluene and quercetin. The authors of the study stated that the $A$. annua essential oil did show antioxidant activity, but it was weak [68].

\section{Nephroprotective effect}

The University of Niš in Niš (Serbia) was also the place where the effect of essential oil from $A$. annua herb on kidney damage in rats, caused by carbon tetrachloride, was evaluated. Urea and creatinine levels were the parameters determining the renal function. In the group of rats given carbon tetrachloride and essential oil (test group), the concentration of both urea and creatinine was significantly lower than in the group of rats given carbon tetrachloride alone (control group). The nephroprotective effect was also confirmed by histopathological examination of the rodents' kidneys, which showed a reduction in damage among the rats treated with $A$. annua essential oil [68].

\section{Anticancer effect}

Researchers from Gyeongsang National University in Jinju and Dong-eui University in Busan (South Korea) have evaluated the antitumour and, in particular, anti-metastatic activity of polyphenols isolated from $A$. annua herb and roots in an in vitro experiment on MDA-MB-231 cells (breast cancer cell line). The study examined the effect of the isolated polyphenols on the adhesion of cancer cells to endothelial cells and on the epithelial-mesenchymal transition (EMT) [53]. EMT is a process in which fixed and polarized epithelial cells transform into cells with a mesenchymal phenotype, which can lead to tissue fibrosis as well as invasion and metastasis of cancer cells [97]. 
The results of the study proved that the polyphenols contained in $A$. annua inhibited the adhesion of MDA-MB-231 cells to endothelial cells. Invasion of tumour cells activated by tumour necrosis factor was also inhibited by, among others, suppression of the EMT transition. The authors of the study indicated that the polyphenols isolated from $A$. annua could be a good agent for inhibiting tumour metastasis [53].

At the Johannes Gutenberg University in Mainz and the Clinic for General Medicine in Hirzacker (Germany), a study was conducted to determine the effect of an $A$. annua extract on prostate cancer. It was based on the immunohistochemistry of tumour material taken from a patient suffering from prostate cancer who had undergone treatment with a preparation containing a concentrate with the $A$. annua extract and a preparation with bicalutamide. The results obtained were compared with the results of immunohistochemistry on two prostate cancer cell lines (PC-3 and DU-145). The results of the study indicate that long-term treatment with the $A$. annua extract in combination with short-term use of bicalutamide causes significant regression of an advanced stage of metastatic prostate cancer [94].

At the People's Hospital of Zhengzhou University and Henan Province People's Hospital in Zhengzhou (China) tests were performed to determine whether dihydroartemisinin (DHA) influences the development of human osteosarcoma cells (cell lines of various malignancy - MG63, U2OS, 143B, and Saos2). The results of the work showed that all the lines were sensitive to DHA. In addition, the line with the highest malignancy (143B) was found to be the most sensitive to DHA. DHA significantly reduced the proliferation of cells of the 143B line and directed them towards apoptosis [58].

In vitro tests for the evaluation of cytotoxic activity of $A$. annua have also been carried out at King Abdullah University of Science and Technology in Thuwal (Saudi Arabia), Research and Development, Qatar Foundation in Doha (Qatar), and at Kuwait University in Kuwait City (Kuwait). Extraction of $A$. annua leaves collected in Jericho and Egypt was carried out with hexane, chloroform, methanol, and water. The experiment was performed on a human breast adenocarcinoma cell line, human lung cancer line, and on the Chinese hamster ovary cell line using Alamar Blue assay and lactate dehydrogenase test. A significant decrease in cell viability (cytotoxic effect) was exhibited by the methanolic extract from the plants collected in Egypt, in contrast to extracts from A. annua leaves from Jericho. The activity of the aqueous extract from the plants from Egypt and the activity of other solvents were not significant [44].

\section{Action in obesity treatment}

The potential role of $A$. annua in the treatment of obesity has been investigated by researchers at Hoseo University in Asan and Konkuk University School of Medicine in Chungju (South Korea). They investigated whether the essential oil from the plant had an effect on cell differentiation of the murine 3T3-L1 preadipocyte line. The oil reduced the accumulation of lipid droplets and the expression of obesity-related proteins such as PPARY (receptor activated by peroxisome proliferators), $C / E B P \alpha$ (proteins that bind to the CCAAT sequence), SREBP-1c (protein that binds to the $1 c$ sterol regulatory element), FAS (fatty acid synthase), and ACC (coenzyme A carboxylase) [43].
In 2016, researchers from the University School of Medicine, Gyeongnam Oriental Medicinal Herb Institute, Gyeongnam National University of Science and Technology, Shinseon F\&V Co. in Gyeongam, and from the Ministry of Food and Drug Safety in Busan (South Korea) investigated the activity of an $A$. annua leaf extract in preventing obesity in mice. The leaves of the plant were extracted with $80 \%$ ethanol (a hydro-ethanolic extract). The extract from $A$. annua leaves was administered to the study group of mice that were fed a high-fat diet for 12 weeks. The results of the work proved that the hydro-ethanolic extract from the leaves of the plant reduced insulin resistance and limited liver steatosis. The concentrations of SREBP-1c, ChREBP (carbohydrate regulatory element binding protein) and cyclooxygenase-2 (COX-2) involved in inflammatory processes were found to have decreased. Increases in the levels of transforming growth factor $\beta 1$ (TGF- $\beta 1$ ) and connective tissue growth factor were also inhibited, which weakened the liver fibrosis process [56].

\section{Importance in Veterinary Medicine}

Researchers from the Instituto de Investigação Agrária de Moçambique in Maputo (Mozambique), the Appalachian Farming Systems Research Center in Beaver, the National Soil Erosion Research Laboratory in West Lafayette, the US Salinity Laboratory in Riverside (United States), and the Brazilian Agricultural Research Corporation in São Carlos (Brazil) have tested extracts from A. annua against Haemonchus contortus (a parasite of mainly in sheep and goats). The scientists extracted $A$. annua leaves with water, $0.1 \%$ sodium bicarbonate solution, dichloromethane, and methanol. Artemisinin was then isolated from the extracts obtained. The highest amount of it was confirmed in the dichloromethane extract (9.8\%). In vitro tests included the egg hatching test (EHT), in which all the extracts were used, and the larval development test, in which only the bicarbonate extract was used. The results of both studies showed that extracts from $A$. annua inhibit the development of parasites, as they reduce the number of hatched eggs and inhibit the development of larvae. The EHT study demonstrated higher activity of the bicarbonate extract. In a subsequent stage of the study, $\mathrm{H}$. contortus-infected sheep were orally given the bicarbonate extract from $A$. annua leaves and pure artemisinin. The number of parasite eggs per gram of animal faeces was then counted. Both the extract and artemisinin proved ineffective. The authors of the study concluded that poor bioavailability of artemisinin and the compounds contained in the extract could have contributed to this outcome [48].

\section{Applications in Cosmetology}

A. annua is used not only by the pharmaceutical industry but also by the cosmetics industry. The European Coslng (Cosmetic Ingredients) database [98] informs that $A$. annua is a species authorized for use in 12 forms. These are agents for the protection and care of the skin and hair, and antibacterial, antioxidant, masking, fragrant, anti-dandruff, moisturizing, and softening substances $(\triangleright$ Table 4). For their production, mainly A. annua herb extract or essential oil is used, as well as the filtrate obtained after fermenta- 
- Table 4 Applications of $A$. annua in cosmetology as recommended by the CosIng database.

\begin{tabular}{|c|c|c|}
\hline Name in CosIng & Description & Application profile \\
\hline $\begin{array}{l}\text { Artemisia annua (leaf/stem)/Ficus carica fruit/Ginkgo } \\
\text { biloba leaf extract }\end{array}$ & $\begin{array}{l}\text { extract of leaves and stems of annual mugwort, } \\
\text { fig fruit, and ginkgo biloba leaves }\end{array}$ & skin care agent \\
\hline Artemisia annua callus extract & extract from annual mugwort callus cultures & $\begin{array}{l}\text { antibacterial agent, antioxidant } \\
\text { substance, skin care agent, hair } \\
\text { care agent, skin protection agent }\end{array}$ \\
\hline Artemisia annua extract & mugwort herb extract & masking agent \\
\hline Artemisia annua herb oil & essential oil of $A$. annua herb & fragrance \\
\hline Artemisia annua leaf extract & mugwort leaf extract & $\begin{array}{l}\text { anti-dandruff agent, antibacterial } \\
\text { agent, fragrance, skin care agent }\end{array}$ \\
\hline Artemisia annua leaf/stem extract & extract of leaves and stems of annual mugwort & skin care agent \\
\hline Artemisia annua meristem cell extract & extract from meristematic cells of annual mugwort & antioxidant \\
\hline Artemisia annua oil & essential oil obtained from annual mugwort herb & $\begin{array}{l}\text { antioxidant, emollient, } \\
\text { humectant, hair care agent }\end{array}$ \\
\hline Artemisia annua seed extract & extract of annual mugwort seeds & antioxidant \\
\hline $\begin{array}{l}\text { Artemisia annua/Citrus junos fruit/ } \\
\text { Pinus densiflora leaf extract }\end{array}$ & $\begin{array}{l}\text { extract from annual mugwort, } C \text {. junos (yuzu) fruit } \\
\text { and } P \text {. densiflora pine leaves }\end{array}$ & skin protection agent \\
\hline $\begin{array}{l}\text { Aspergillus/apricot kernel/Artemisia annua/Aquilaria } \\
\text { agallocha stem/Elettaria cardamomum seed/Cordy- } \\
\text { ceps sinensis/Hericium erinaceum/Polyporus umbella- } \\
\text { tus/wheat flour/Xanthium strumarium fruit ferment } \\
\text { extract filtrate }\end{array}$ & $\begin{array}{l}\text { filtrate of product obtained by fermentation of apri- } \\
\text { cot kernels, annual mugwort herb, A. agallocha } \\
\text { stalks, E. cardamomum seeds, C. sinensis fungus, } \\
\text { H. erinaceum fungus, whole } P \text {. umbellatus, wheat } \\
\text { flour, and turnip fruit by fungi of the genus Aspergillus }\end{array}$ & emollient \\
\hline $\begin{array}{l}\text { Bacillus/apricot seed/Artemisia annua extract/ } \\
\text { Phaseolus angularis seed/soybean seed/wheat bran/ } \\
\text { Xanthium strumarium fruit extract ferment extract }\end{array}$ & $\begin{array}{l}\text { extract of product obtained by fermentation of } \\
\text { apricot seeds, annual mugwort extract, azuki bean } \\
\text { seeds, soybean oil, wheat bran and turnip fruit by } \\
\text { Bacillus bacteria }\end{array}$ & skin care agent \\
\hline $\begin{array}{l}\text { Lactobacillus/Leuconostoc/Artemisia annua extract/ } \\
\text { polysorbate } 80 \text { ferment lysate filtrate }\end{array}$ & $\begin{array}{l}\text { lysate filtrate of product obtained by fermentation of } \\
\text { extract from annual mugwort and polysorbate } 80 \text { by } \\
\text { Lactobacillus and Leuconostoc bacteria }\end{array}$ & skin care agent \\
\hline
\end{tabular}

tion of the leaves by microorganisms such as Lactobacillus spp., Aspergillus spp., Bacillus spp., and Leuconostoc spp.

The $A$. annua species is used as an ingredient in skincare cosmetics such as shampoos, essences, serums, hand and eye creams, masks, lotions, and tonics. These products are effective in moisturizing the skin of the hands, head, face, and the whole body. They also have a protective and cleansing effect.

Cosmetics that have $A$. annua in their composition can be found in the offers of many foreign companies operating in Europe, Asia, and North America. In Europe, they are German (e.g., Curamisia) and Swiss (e.g., Kingnature) companies, while in North America they are American companies (Aromahealth and Celvos). Products containing $A$. annua are also offered by South Korean producers (Farmgrain, Missha, Neogen, KB Cosmetics, and d'Alba Piedmont, among others).

\section{Applications in the Food Industry}

The green parts of $A$. annua are consumed as a vegetable. The species is also used as a source of green dye and as an ingredient in vermouths $[8,29]$.

\section{Safety of Use}

A. annua can cause inflammation of the skin, and due to its highly allergenic pollen, allergies may develop in susceptible people. Documented side effects experienced after using extracts of the herb are abdominal pain, bradycardia, diarrhoea, nausea, vomiting, decreased appetite, flu-like symptoms, reticulocytopenia, and fever. Consumption of preparations with $A$. annua, such as antimalarial drugs, taken in small doses for a short time should not cause side effects. The use of preparations based on this species is contraindicated in patients with ulcers and gastrointestinal disorders $[29,99,100]$.

Artemisinin and its derivatives used in malaria are well tolerated, however, they can cause gastrointestinal disorders, dizziness, tinnitus, and bradycardia. The most serious side effect are type 1 hypersensitivity reactions [101, 102]. The EFSA (European Food Safety Authority) lists $A$. annua leaves as a raw material that is not health-neutral due to the high concentration of camphor $(2.58-37.5 \%)$ in the composition of the oil [103].

\section{Summary}

A. annua, a species that has become famous around the world in connection with the 2015 Nobel Prize for discovering artemisinin 
in its composition and proving its antimalarial activity, having the status of a pharmacopoeial species in China and Vietnam and having a monograph published by WHO, is currently still a subject of phytochemical and pharmacological research.

Research on the chemical composition has proved the presence in the species (in the leaves and herb) of mainly a number of specific sesquiterpene lactones, essential oil, flavonoids, coumarins, and phenolic acids.

Modern pharmacological studies of the herb and/or leaf extracts and/or the essential oil have proven their antiprotozoal (not only against Plasmodium spp.), antibacterial, antifungal, immunosuppressive, anti-inflammatory, analgesic, antioxidant, anticancer, and nephroprotective activities. Some of these professionally proven activities confirm the medicinal properties of this species that have been known for a long time. The novelty is primarily the proven antioxidant, anti-inflammatory, analgesic, and nephroprotective activities.

Interestingly, this species has become an object of special interest of the cosmetics industry in Europe, North America, and East Asia. In the European CosIng (Cosmetic Ingredients) database, this species appears in as many as 12 forms that are possible for cosmetic applications.

The food industry treats the species as a vegetable, an ingredient of vermouths, and a source of dye.

A review of the scientific literature on the species shows that this seemingly well-known and tested medicinal plant can, thanks to the use of modern research methodology in the fields of phytochemistry and pharmacology, be a source of new discoveries regarding its chemical composition and can be used in previously unknown areas of medicinal and paramedicinal applications.

\section{Contributors' Statement}

Data collection: H.E., J.S., P.K., A.R., and A.S.; design of the study: H.E.; analysis and interpretation of the data: H.E., J.S., P.K., A.R., and A.S.; drafting the manuscript: H.E., J.S., P.K., A.R., and A.S.; critical revision of the manuscript: H.E. and A.S. All authors read and approved the manuscript in its final form.

\section{Acknowledgements}

This research was funded by grant number N42/DBS/000010 supported by the Polish Ministry of Science and Higher Education.

\section{Conflict of Interest}

The authors declare that they have no conflict of interest.

\section{References}

[1] Efferth T, Zacchino S, Georgiev MI, Liu L, Wagner H, Panossian A. Nobel Prize for artemisinin brings phytotherapy into the spotlight. Phytomedicine 2015; 22: 1-4

[2] Ekiert H, Kubica P, Kwiecień I, Szopa A. Nagroda Nobla 2015 z medycynyzwycięstwo badań z zakresu fitochemii, bakteriologii i farmakologii. Farm Pol 2016; 72: 315-326

[3] Aftab T, Ferreira JFS, M. Masroor M Khan A. Naeem M. Artemisia annua Pharmacology and Biotechnology. Berlin, Heidelberg: Springer Berlin Heidelberg; 2014
[4] Bora KS, Sharma A. The genus Artemisia: a comprehensive review. Pharm Biol 2011; 49: 101-109

[5] Alesaeidi S, Miraj S. A systematic review of anti-malarial properties, immunosuppressive properties, anti-inflammatory properties, and anticancer properties of Artemisia annua. Electron Physician 2016; 8: 3150 3155

[6] Das S. Artemisia annua (qinghao): a pharmacological review. Int J Pharm Sci Res 2012; 3: 4573-4577

[7] Brown GD. The biosynthesis of artemisinin (qinghaosu) and the phytochemistry of Artemisia annua L. (qinghao). Molecules 2010; 15: $7603-$ 7698

[8] World Health Organization. WHO monograph on good agricultural and collection practices (GACP) for Artemisia annua L. Geneva: World Health Organization; 2006: 300. Accessed September 10, 2020 at: https:// apps.who.int/iris/bitstream/handle/10665/43509/9241594438_eng. pdf;jsessionid=A927467AFDCFEA879E90A88074766735? sequence $=1$

[9] Ding F, Ma T, Hao M, Wang Q, Chen S, Wang D, Huang L, Zhang X, jiang D. Mapping worldwide environmental suitability for Artemisia annua L. Sustainability 2020; 12: 1309

[10] Editorial Committee on Flora of the People's Republic of China of the Chinese Academy of Sciences. Flora of the People's Republic of China. 2nd ed. Beijing: Science Press; 1991

[11] van Wyk BE, Wink M. Medicinal Plants of the World. Portland: Timber Press; 2004

[12] Willcox M. Artemisia species: From traditional medicines to modern antimalarials-and back again. J Altern Complement Med 2009; 15: 101-109

[13] Pellicer ], Saslis-Lagoudakis CH, Carrió E, Ernst M, Garnatje T, Grace OM, Gras A, Mumbrú M, Vallès J, Vitales D, Rønsted N. A phylogenetic road map to antimalarial Artemisia species. J Ethnopharmacol 2018; 225: 1-9

[14] Phuong Thao NT, Thi Thuy N, Minh Hoi T, Huy Thai T, Muselli A, Bighelli A, Castola V, Casanova J. Artemisia vulgaris L. from Vietnam: chemical variability and composition of the oil along the vegetative life of the plant. J Essent Oil Res 2004; 16: 358-361

[15] Nguyen T. Vietnamese Pharmacopoeia. Hanoi: Vietnamese Pharmacopoeia Commission; 2005

[16] Chinese Pharmacopoeia Commission. Pharmacopoeia of the People's Republic of China. Beijing: China Chemical Industry Press; 2005

[17] van der Kooy F, Sullivan SE. The complexity of medicinal plants: the traditional Artemisia annua formulation, current status and future perspectives. J Ethnopharmacol 2013; 150: 1-13

[18] Garcia LC. A review of Artemisia annua L.: Its genetics, biochemical characteristics, and anti-malarial efficacy. Int J Sci Technol 2015; 5: 38-46

[19] Ryu JH, Lee SJ, Kim MJ, Shin JH, Cho KM, Sung NJ. Antioxidant and anticancer activities of Artemisia annua L. and determination of functional compounds. J Korean Soc Food Sci Nutr 2011; 40: 509-516

[20] Slezakova S, Ruda-Kucerova ]. Anticancer activity of artemisinin and its derivatives. Anticancer Res 2017; 37: 5995-6003

[21] Rolta R, Salaria D, Kumar V, Sourirajan A, Dev K. Phytocompounds of Rheum emodi, Thymus serpyllum and Artemisia annua inhibit COVID-19 binding to ACE2 receptor: in silico approach. Res Sq 2020; 5: 1-23

[22] Law S, Leung AW, Xu C. Is the traditional Chinese herb "Artemisia annua" possible to fight against COVID-19? Integr Med Res 2020; 9: 100474

[23] Dong R, Xiong X, Chen G. Discuss about the application of Artemisia annua prescriptions in the treatment of COVID-19. TMR Mod Herb Med 2020; 3: 1-2

[24] Kapepula PM, Kabengele JK, Kingombe M, Van Bambeke F, Tulkens PM, Sadiki Kishabongo A, Decloedt E, Zumla A, Tiberi S, Suleman F, Tshilolo L, Muyembe-TamFum J, Zumla A, Nachega JB. Artemisia spp. derivatives for COVID-19 treatment: anecdotal use, political hype, treatment potential, challenges, and road map to randomized clinical trials. Am J Trop Med Hyg 2020; 103: 960-964 
[25] Yu J, Wang G, Jiang N. Study on the repairing effect of cosmetics containing Artemisia annua on sensitive skin. J Cosmet Dermatological Sci Appl 2020; 10: 8-19

[26] Missouri Botanical Garden. Accessed August 31, 2020 at: www.Tropicos. org

[27] GBIF. GBIF Home Page. Accessed September 20, 2020 at: https://www. gbif.org/

[28] The Plant List. Accessed September 1, 2020 at: http://www.theplantlist. org/

[29] The Herb Society of America. Artemesia: an essential Guide. 2014. Accessed September 1, 2020 at: https://www.herbsociety.org/file_ download/inline/d52eae8c-be89-497d-94b3-7fc8da4105f1

[30] Zeb S, Ali A, Zaman W, Zeb S, Ali S, Ullah F, Shakoor A. Pharmacology, taxonomy and phytochemistry of the genus Artemisia specifically from Pakistan: a comprehensive review. Pharm Biomed Res 2019; 4: 1-12

[31] Ferreira J, Anick J. Annual Wormwood (Artemisia annua L.). New Crop Fact Sheet 2009. Accessed August 30, 2020 at: https://hort.purdue. edu/newcrop/CropFactSheets/artemisia.pdf

[32] Sudnik-Wójcikowska B. Rośliny synantropijne. Warszawa: Multico; 2011

[33] Tu Y. From Artemisia annua L. to Artemisinins. The Discovery and Development of Artemisinins and antimalarial Agents. London, UK: Chemical Industry Press, Elsevier Inc.; 2017

[34] Wąsowicz A. Occurrence of Artemisia annua L. in Wrocław city area (Lower Silesia, Poland). Bot Silesiaca 2002; 1: 141-146

[35] Gingade S, Varghese TS, Manivel P. Cultivation of Artemisia (Artemisia annua Linn.). Boriavi: ICAR - Directorate of medicinal and aromatic plants research, Boriavi, Anand, Gujarat; 2014

[36] Willcox M, Bodeker G, Rasoanaivo P, Addae-Kyereme J. Traditional medicinal Plants and Malaria. Boca Raton: CRC Press; 2004

[37] Verma RK, Chauhan A, Verma RS, Gupta AK. Influence of planting date on growth, artemisinin yield, seed and oil yield of Artemisia annua L. under temperate climatic conditions. Ind Crops Prod 2011; 34: 860-864

[38] Weathers PJ, Arsenault PR, Covello PS, McMickle A, Teoh KH, Reed DW. Artemisinin production in Artemisia annua: studies in planta and results of a novel delivery method for treating malaria and other neglected diseases. Phytochem Rev 2011; 10: 173-183

[39] Nafis T, Akmal M, Ram M, Alam P, Ahlawat S, Mohd A, Zainul Abdin M. Enhancement of artemisinin content by constitutive expression of the HMG-CoA reductase gene in high-yielding strain of Artemisia annua L. Plant Biotechnol Rep 2011; 5: 53-60

[40] Nair P, Misra A, Singh A, Shukla AK, Gupta MM, Gupta AK, Gupta V, Khanuja SP, Shasany AK. Differentially expressed genes during contrasting growth stages of Artemisia annua for artemisinin content. PLoS One 2013; 8: e60375

[41] Graham LA, Besser K, Blumer S, Branigan CA, Czechowski T, Elias L, Guterman I, Harvey D, Isaac PG, Khan AM, Larson TR, Li Y, Pawson T, Penfield T, Rae AM, Rathbone DA, Reid S, Ross J, Smallwood MF, Segura V, Townsend T, Vyas D, Winzer T, Bowles D. The genetic map of Artemisia annua $\mathrm{L}$. identifies loci affecting yield of the antimalarial drug artemisinin. Science 2010; 327: 328-331

[42] Marinas IC, Oprea E, Chifiriuc MC, Badea IA, Buleandra M, Lazar V. Chemical composition and antipathogenic activity of Artemisia annua essential oil from Romania. Chem Biodivers 2015; 12: 1554-1564

[43] Hwang DI, Won KJ, Kim DY, Yoon SW, Park JH, Kim B, Lee HM. Anti-adipocyte differentiation activity and chemical composition of essential oil from Artemisia annua. Nat Prod Commun 2016; 11: 539-542

[44] Nageeb A, Al-Tawashi A, Mohammad Emwas AH, Abdel-Halim Al-Talla Z, Al-Rifai N. Comparison of Artemisia annua bioactivities between traditional medicine and chemical extracts. Curr Bioact Compd 2014; 9: $324-332$
[45] Kumar Ashok P, Upadhyaya K. Preliminary phytochemical screening and physico-chemical parameters of Artemisia absinthium and Artemisia annua. J Pharmacogn Phytochem 2013; 1: 2668735

[46] Weathers PJ, Towler M, Hassanali A, Lutgen P, Engeu PO. Dried-leaf Artemisia annua: A practical malaria therapeutic for developing countries? World J Pharmacol 2014; 3: 39-55

[47] Bora KS, Sharma A. The genus Artemisia: a comprehensive review. Pharm Biol 2011; 49: 101-109

[48] Cala AC, Ferreira JFS, Chagas ACS, Gonzalez JM, Rodrigues RA, Foglio MA Oliveira MC, Sousa IM, Magalhães PM, Barioni Júnior W. Anthelmintic activity of Artemisia annua L. extracts in vitro and the effect of an aqueous extract and artemisinin in sheep naturally infected with gastrointestinal nematodes. Parasitol Res 2014; 113: 2345-2353

[49] Elfawal MA, Towler M], Reich NG, Golenbock D, Weathers PJ, Rich SM. Dried whole plant Artemisia annua as an antimalarial therapy. PLoS One 2012; 7: 1-7

[50] Akhila A, Thakur RS, Popli SP. Biosynthesis of artemisinin in Artemisia annua. Phytochemistry 1987; 26: 1927-1930

[51] Weathers PJ, Towler M]. The flavonoids casticin and artemetin are poorly extracted and are unstable in an Artemisia annua tea infusion. Planta Med 2012; 78: 1024-1026

[52] Ferreira JFS, Luthria DL, Sasaki T, Heyerick A. Flavonoids from Artemisia annua $\mathrm{L}$. as antioxidants and their potential synergism with artemisinin against malaria and cancer. Molecules 2010; 15: 3135-3170

[53] Ko YS, Lee WS, Panchanathan R, Joo YN, Choi YH, Kim GS, Jung JM, Ryu $\mathrm{CH}$, Shin SC, Kim HJ. Polyphenols from Artemisia annua L inhibit adhesion and EMT of highly metastatic breast cancer cells MDA-MB-231. Phyther Res 2016; 20: 1180-1188

[54] Carbonara T, Pascale R, Argentieri MP, Papadia P, Fanizzi FP, Villanova L, Avato P. Phytochemical analysis of a herbal tea from Artemisia annua $\mathrm{L}$. J Pharm Biomed Anal 2012; 62: 79-86

[55] De Donno A, Grassi T, Idolo A, Guido M, Papadia P, Caccioppola A, Villanova L, Merendino A, Bagordo F, Fanizzi FP. First-time comparison of the in vitro antimalarial activity of Artemisia annua herbal tea and artemisinin. Trans R Soc Trop Med Hyg 2012; 106: 696-700

[56] Kim KE, Ko KH, Heo RW, Yi CO, Shin HJ, Kim JY, Park JH, Nam S, Kim H, Roh GS. Artemisia annua leaf extract attenuates hepatic steatosis and inflammation in high-fat diet-fed mice. J Med Food 2016; 19: 290-299

[57] Silva LF, Magalhães PM, Costa MR, Alecrim Md, Chaves FC, Hidalgo Ade F, Pohlit AM, Vieira PP. In vitro susceptibility of Plasmodium falciparum Welch field isolates to infusions prepared from Artemisia annua L. cultivated in the Brazilian Amazon. Mem Inst Oswaldo Cruz 2012; 107: 859866

[58] Tang C, Zhao Y, Huang S, Jin Y, Liu J, Luo J, Zheng J, Shi D. Influence of Artemisia annua extract derivatives on proliferation, apoptosis and metastasis of osteosarcoma cells. Pak J Pharm Sci 2015; 28: 773-779

[59] Melillo de Magalhães P, Dupont I, Hendrickx A, Joly A, Raas T, Dessy S, Sergent T, Schneider Y]. Anti-inflammatory effect and modulation of cytochrome P450 activities by Artemisia annua tea infusions in human intestinal Caco-2 cells. Food Chem 2012; 134: 864-871

[60] Phadungrakwittaya R, Chotewuttakorn S, Piwtong M, Thamsermsang O, Laohapand T, Akarasereenont P. Identification of apigenin and luteolin in Artemisia annua L. for the quality control. Siriraj Med J 2019; 71: 240245

[61] Han J, Ye M, Qiao X, Xu M, Wang BR, Guo DA. Characterization of phenolic compounds in the Chinese herbal drug Artemisia annua by liquid chromatography coupled to electrospray ionization mass spectrometry. J Pharm Biomed Anal 2008; 47: 516-525

[62] Engeu PO, Omujal F, Agwaya M, Kyakulaga H, Obua C. Variations in antimalarial components of Artemisia annua Linn. from three regions of Uganda. Afr Health Sci 2015; 15: 828-834

[63] Abid Ali Khan MM, Jain DC, Bhakuni RS, Zaim M, Thakur RS. Occurrence of some antiviral sterols in Artemisia annua. Plant Sci 1991; 75: 161-165 
[64] Kazemi M. Essential oil of the aerial parts of Artemisia annua (Asteraceae) from Iran. J Essent Oil Bearing Plants 2015; 18: 1003-1005

[65] Singh ND, Kumar S, Daniell H. Expression of $\beta$-glucosidase increases trichome density and artemisinin content in transgenic Artemisia annua plants. Plant Biotechnol ] 2016; 14: 1034-1045

[66] Brisibe EA, Umoren UE, Brisibe F, Magalhäes PM, Ferreira JFS, Luthria D, Wu X, Prior RL. Nutritional characterisation and antioxidant capacity of different tissues of Artemisia annua L. Food Chem 2009; 115: 1240-1246

[67] Donato R, Santomauro F, Bilia AR, Flamini G, Sacco C. Antibacterial activity of Tuscan Artemisia annua essential oil and its major components against some foodborne pathogens. LWT - Food Sci Technol 2015; 64: $1251-1254$

[68] Radulović NS, Randjelović PJ, Stojanović NM, Blagojević PD, StojanovićRadić ZZ, Ilić IR, Djordjević VB. Toxic essential oils. Part II: Chemical, toxicological, pharmacological and microbiological profiles of Artemisia annua L. volatiles. Food Chem Toxicol 2013; 58: 37-49

[69] Cafferata LFR, Gatti WO, Mijailosky S. Secondary gaseous metabolites analyses of wild Artemisia annua L. Molec Med Chem 2010; 21: 48-52

[70] Yan T, Chen M, Shen Q, Li L, Fu X, Pan Q, Tang Y, Shi P, Lv Z, Jiang W, Ma YN, Hao X, Sun X, Tang K. Homeodomain protein 1 is required for jasmonate-mediated glandular trichome initiation in Artemisia annua. New Phytol 2017; 213: 1145-1155

[71] Efferth T, Zacchino S, Georgiev MI, Liu L, Wagner H, Panossian A. Nobel Prize for artemisinin brings phytotherapy into the spotlight. Phytomedicine 2015; 22: A1-A3

[72] Golenser J, Waknine JH, Krugliak M, Hunt NH, Grau GE. Current perspectives on the mechanism of action of artemisinins. Int J Parasitol 2006; 36: $1427-1441$

[73] Długońska H. The Nobel Prize 2015 in physiology or medicine for highly effective antiparasitic drugs. Ann Parasitol 2015; 61: 299-301

[74] Singh Bhakuni R, Singh T, Prakash Kahol A, Amit T, Sundeep T, Tandon S, Preet Singh Khanuja S. Single pot conversion of artemisinin into artemether. 2002. Accessed September 2, 2020 at: https://patents.google. com/patent/US6683193B2/en

[75] Ching FM. Chinese Herbal Drug Research Trends - Felix M. Ching. New York: Nova Biomedical Book; 2007

[76] Unschuld PU. Medicine in China: A History of Pharmaceutics. Los Angeles, London: University of California Press Berkeley; 1986

[77] Riddle J. Goddesses, Elixirs, and Witches: Plants and Sexuality throughout human History. New York: Elsevier Inc.; 2010

[78] Błaszczak T. Podstawy medycyny chińskiej. Kraków: Proherba; 2012

[79] Neill US. From branch to bedside: Youyou Tu is awarded the 2011 Lasker DeBakey Clinical Medical Research Award for discovering artemisinin as a treatment for malaria. J Clin Invest 2011; 121: 2768-3773

[80] Mueller MS, Karhagomba IB, Hirt HM, Wemakor E. The potential of Artemisia annua L. as a locally produced remedy for malaria in the tropics: agricultural, chemical and clinical aspects. J Ethnopharmacol 2000; 73: 487-493

[81] Zhang YX, Sun HX. Immunosuppressive effect of ethanol extract of Artemisia annua on specific antibody and cellular responses of mice against ovalbumin. Immunopharmacol Immunotoxicol 2009; 31: 625-630

[82] Ram S. Research output on Artemisia (Artemisia annua): a bibliometric study. Ann Libr Inf Stud 2011; 58: 237-248

[83] Sadiq A, Hayat MQ, Ashraf M. Ethnopharmacology of Artemisia annua L.: a Review. In: Aftab T, Ferreira JFS, Khan MMA, Naeem M. Artemisia Annua - Pharmacology and Biotechnology. Berlin, Heidelberg: Springer Berlin Heidelberg; 2014: 9-25

[84] World Health Organization. Guidelines for the Treatment Malaria, 3rd Edition. Accessed September 11, 2020 at: https://www.who.int/ publications/i/item/9789241549127

[85] Chrubasik C, Jacobson RL. The development of artemisinin resistance in malaria: reasons and solutions. Phyther Res 2010; 24: 1104-1106
[86] Byakika-Kibwika P, Lamorde M, Mayanja-Kizza H, Khoo S, Merry C, Van Geertruyden JP. Artemether-lumefantrine combination therapy for treatment of uncomplicated malaria: the potential for complex interactions with antiretroviral drugs in HIV-infected individuals. Malar Res Treat 2011; 2011: 1-5

[87] Mueller MS, Runyambo N, Wagner I, Borrmann S, Dietz K, Heide L. Randomized controlled trial of a traditional preparation of Artemisia annua L. (annual wormwood) in the treatment of malaria. Trans R Soc Trop Med Hyg 2004; 98: 318-321

[88] Zime-Diawara H, Ganfon H, Gbaguidi FA, Gbaguidi F, Yemoa A, Bero J, Jansen O, Evrard B, Moudachirou M, Frederich M, Quetin-Leclercq J. The antimalarial action of aqueous and hydro alcoholic extracts of Artemisia annua L. cultivated in Benin: in vitro and in vivo studies. JAPS 2015; 7: 817-823

[89] Eckstein-Ludwig U, Webb RJ, Van Goethem ID, East JM, Lee AG, Kimura M, O’Neill PM, Bray PG, Ward SA, Krishna S. Artemisinins target the SERCA of Plasmodium falciparum. Nature 2003; 424: 957-961

[90] Islamuddin M, Farooque A, Dwarakanath BS, Sahal D, Afrin F. Extracts of Artemisia annua leaves and seeds mediate programmed cell death in Leishmania donovani. J Med Microbiol 2012; 61: 1709-1718

[91] Noori S, Naderi GA, Hassan ZM, Habibi Z, Bathaie SZ, Hashemi SM. Immunosuppressive activity of a molecule isolated from Artemisia annua on DTH responses compared with cyclosporin A. Int Immunopharmacol 2004; 4: 1301-1306

[92] Stebbings S, Beattie E, McNamara D Hunt S. A pilot randomized, placebo-controlled clinical trial to investigate the efficacy and safety of an extract of Artemisia annua administered over 12 weeks, for managing pain, stiffness, and functional limitation associated with osteoarthritis of the hip and knee. Clin Rheumatol 2016; 35: 1829-1836

[93] Iqbal S, Younas U, Chan KW, Zia-Ul-Haq M, Ismail M. Chemical composition of Artemisia annua L. leaves and antioxidant potential of extracts as a function of extraction solvents. Molecules 2012; 17: 6020-6032

[94] Michaelsen FW, Saeed MEM, Schwarzkopf J, Efferth T. Activity of Artemisia annua and artemisinin derivatives, in prostate carcinoma. Phytomedicine 2015; 22: 1223-1231

[95] Derda M, Hadaś E, Cholewiński M, Skrzypczak Ł, Grzondziel A, Wojtkowiak-Giera A. Artemisia annua L. as a plant with potential use in the treatment of acanthamoebiasis. Parasitol Res 2016; 115: 16351639

[96] Grajek W, Olejnik A, Stanaszek K. Kultury komórkowe nabłonka jelitowego jako model do badania transportu trans nabłonkowego. Biotechnologia 2006; 2: 148-165

[97] Pieniążek M, Donizy P, Ziętek M, Szynglarewicz B, Matkowski R. The role of TGF- $\beta$-related signal transduction pathways in pathogenesis of epithelial-mesenchymal transition as a key element in cancer development and progression. Postepy Hig Med Dosw 2012; 66: 583-591

[98] European Commission Cosing. Cosing - Cosmetics Database. Accessed September 15, 2020 at: https://ec.europa.eu/growth/sectors/ cosmetics/cosing_en

[99] Leng X, Ye ST. An investigation on in vivo allergenicity of Artemisia annua leaves and stems. Asian Pac J Allergy Immunol 1987; 5: 125-128

[100] Tang R, Sun JL, Yin J, Li Z. Artemisia allergy research in China. Biomed Res Int 2015; 2015: 179426

[101] Taylor WRJ, White NJ. Antimalarial drug toxicity: a review. Drug Saf 2004; 27: 25-61

[102] Mclntosh H, Olliaro P. Artemisinin derivatives for treating uncomplicated malaria. Cochrane Database Syst Rev 2000; (1999): CD000256

[103] European Food Safety Authority. Compendium of botanicals reported to contain naturally occuring substances of possible concern for human health when used in food and food supplements. EFSA J 2012; 10: 2663 